\title{
Keterkaitan Corporate Governance Dengan Corporate Social Responsibility
}

\author{
R. Ery Wibowo Agung $S$ \\ Jurusan Akuntansi Fakultas Ekonomi Universitas Muhammadiyah Semarang \\ Jl. Kasipah 12 Semarang
}

\begin{abstract}
Makalah ini membahas tentang keterkaitan antara Corporate Gorvenance dengan Corporate Social Responsibility. Keduanya baik Corporate Social Responsibility (CSR) dalam perspektif teori legitimasi maupun Corporate Gorvenence keduanya saling melengkapi membentuk fungsi objektif dalam menghadapi kendala yang dihadapi oleh perusahaan. Disatu sisi CG dapat meminimalkan biaya agensi disisi lain CSR dapat mengatasi beban ilegitimasi dari stakeholdernya. Baik CG maupun CSR memiliki hubungan imbal balik yang membentuk fungsi yang mampu meningkatkan nilai perusahaan dan meningkatkan kinerja social dan kinerja keuangan dalam jangka panjang.
\end{abstract}

Key words : corporate governance, corporate social responsibility, problem agensi, legitimasi, kinerja keuangan, kinerja sosial

\section{Pendahuluan}

Beberapa tahun terakhir banyak perusahaan semakin menyadari pentingnya penerapan program Corporate Social Responsibility (CSR) sebagai bagian dari strategi bisnisnya. Penelitian Basalamah \& Jermias (2005) menunjukkan bahwa salah satu alasan manajemen melakukan pelaporan social adalah untuk alas an strategis. Meskipun belum bersifat mandatory tetapi dapat dikatakan bahwa hampeir semua perusahaan yang terdaftar di Bursa Efek Indonesia mengungkapkan informasi mengenai CSR dalam laporan tahunannya.

Hal tersebut di atas menunjukkan telah terjadi pergeseran paradigma pertanggungjawaban perusahaan dari shareholder orientation ke stakeholder orientation merupakan satu keniscayaan. Kondisi tersebut muncul akibat dampak negatif bergesernya paradigma tersebut. Esensi teori legitimasi menjelaskan bahwa untuk menjamin dan menjaga keberpihakan (legitimasi) stakeholder baik internal maupun eksternal perusahaan perlu menjamin kongruensi antara keberadaan dan tujuan perusahaan terhadap pengharapan stakeholder (Gray, et al, 1996; Deegan 2000; Gray O’Donovan,2000). Artinya bila kongruesian manajemen melakukan pelaporan sos antara keduanya terganggu maka akan mengurangi legitimasi perusahaan. Gary O'Donovan (2002) memberikan 
ilustrasi posisi legitimasi antara perusahaan dan stakeholder, digambarkan dalam sebuah bagan maka wilayah legitimasi sebagai berikut :

\section{Daerah Legitimacy Gap}

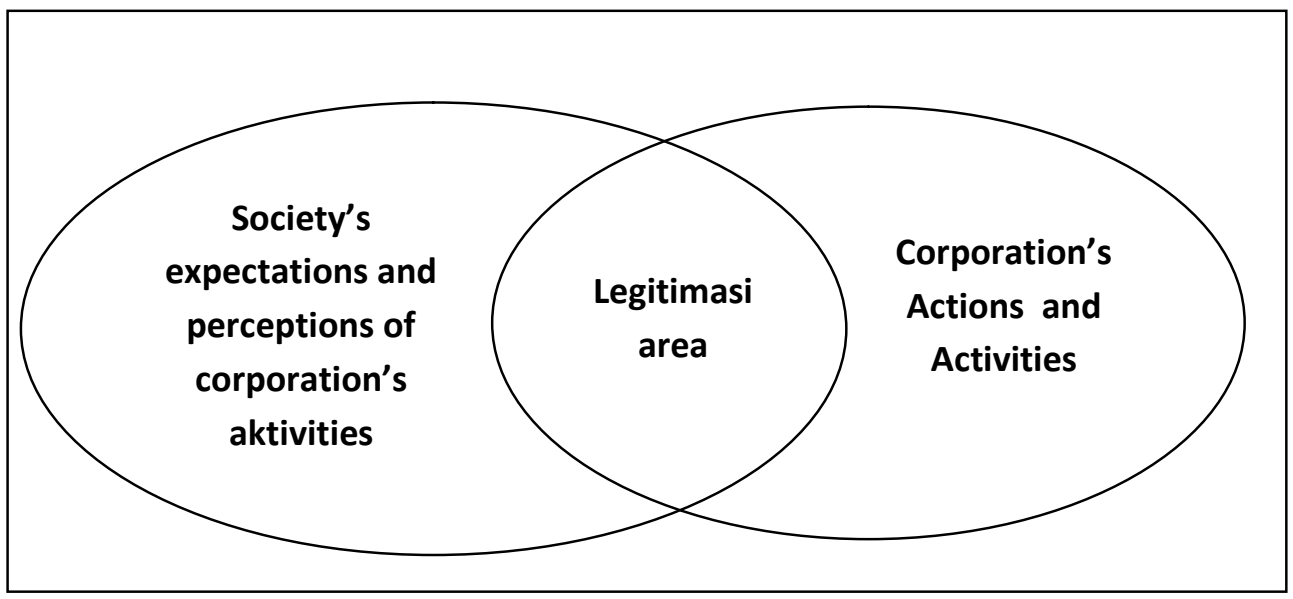

Sumber : Gary O’Donovan (2002)

Dilihat dari sudut pandang konsep entity bahwa terjadi pemisahan tegas antara perusahaan, shareholder dan stakeholder dalam pengelolaan dan operasional perusahaan. Pemisahaan posisi tersebut, memunculkan asimetri informasi dan persepsi, yang dapat menumbuhkan illegitimaucy. Sementara itu corporate gorvenance (CG) menganjurkan praktik keterbukaan perusahaan terhadap para pihak yang berkepentingan. Belkaui dan karpik (1989) menyatakan bahwa pengungkapan social mengandung economic dan social consequence. Pengungkapan social dapat memberikan informasi peran dan fungsi perusahaan ditengah lingkungan dan masyarakat sehingga mengurangi kesalahpahaman. Sedang economic consequence pengungkapan social dapat meningkatkan kinerja keuangan. Shane dan Spicer (1983) berpendapat bahwa tingkat kepedulian social perusahaan berpengaruh terhadap kinerja perusahaan.

Keberpihakan perusahaan terhadap masyarakat dan lingkungan lewat berbagai pengeluaran social perlu diungkapkan terhadap para pihak yang berkepentingan. Pengungkapan social (social disclosure) tersebut merupakan bagian pelaksanaan legitimasi serta perwujudan akuntabilitas perusahaan yang diproksikan dalam corporate gorvenance. Corporate gorvenance merupakan salah satu elemen kunci dalam meningkatkan efisiensi ekonomis yang meliputi serangkaian hubungan antara manajemen perusahaan, dewan komisaris, para pemegang saham dan stakeholder lainnya. Corporate gorvenance (CG) juga memberikan suatu struktur yang memfasilitasi penentuan sasaransasaran dari suatu perusahaan dan sebagai sarana untuk menentukan teknik monitoring kinerja 
(Restuningdiah,2010). Penelitian tentang pengungkapan tanggung jawab social dikaitkan dengan corporate governance dilakukan oleh Novita \& Djakman (2008) serta Farook\&Lanis (2005) dalam Murwaningsari (2009). Penelitian tersebut menemukan bahwa Islamic governance ( sebagai proksi corporate governance di bank Islam) terbukti berpengaruh positip secara signifikan terhadap pengungkapan tanggungjawab social. Demikian juga dengan hasil penelitian Murwaningsari (2009) yang membuktikan GCG yang diamati melalui kepemilikan managerial dan institusional mempunyai pengaruh terhadap [engungkapan pertanggungjawaban social.

Dalam makalah ini akan dibahas keterkaitan antara CG dengan CSR lebih jauh lagi. karena bagaimanapun juga Corporate Social Responsibility (CSR) dalam perspektif teori legitimasi dan Corporate Gorvenence keduanya saling melengkapi membentuk fungsi objektif dalam menghadapi kendala yang dihadapi oleh perusahaan. (Beltratti, 2005)

\section{Corporate Gorvernance}

Corporate Governance (CG) merupakan konsep yang didasarkan pada teori keagenan, dan diharapkan bisa berfungsi sebagai alat untuk memberikan keyakinan kepada para investor bahwa mereka akan menerima return atas dana yang telah mereka investasikan. CG berkaitan dengan bagaimana para investor yakin bahwa manajer akan memberikan keuntungan bagi mereka, yakin bahwa manajer tidak akan mencuri/menggelapkan atau menginvestasikan ke dalam proyek-proyek yang tidak menguntungkan berkaitan dengan dana/capital yang telah ditanamkan oleh investor dan berkaitan dengan bagaimana para investor mengontrol para manajer (shleifer \& Vishny, 1997)

Corporate gorvenance diharapkan dapat berfungsi untuk menekan atau menurunkan biaya keagenan atau agency cost (Ujiyanto \& Pramuka, 2007). Prilaku manipulasi oleh manajer yang berawal dari konflik kepentingan tersebut dapat diminimumkan melalui suatu mekanisme monitoring yang bertujuan untuk menyelaraskan bebagai kepentingan. Teori keagenan mendasari munculnya praktik manajemen laba karena pemisahan kepemilikan oleh principal dengan pengendalian oleh agen dalam suatu perusahaan yang cenderung menimbulkan konflik keagenan antara principal dan agen. Manajemen selaku pengelola perusahaan memiliki informasi tentang perusahaan lebih banyak dan lebih dahulu daripada principal sehingga terjadi asimetri informasi yang memungkinkan manajemen bersikap oportunistik dengan cara melakukan praktek akuntansi yang berorientasi pada laba untuk mencapai suatu kinerja tertentu. Asimetri Informasi juga memberikan peluang bagi manajemen untuk melaporkan laba semu yang dapat menyebabkan menurunnya nilai perusahaan di masa yang akan dating. Meskipun demikian dampak manajemen laba tidak hanya mempengaruhi pemilik perusahaan tetapi juga mempunyai pengaruh yang kuat 
pada stakeholder. Sementara itu stakeholder merupakan sekelompok orang yang mempunyai resiko sebagai akibat bentuk investasi yang berupa modal, sumber daya manusia atau sesuatu yang bernilai pada suatu perusahaan (Clarkson, 1994)

Asimetri Informasi, dalam sudut pandang teori agency merupakan informasi yang tidak seimbang yang disebabkan karena adanya distribusi informasi yang tidak sama antara prinsipal dan agen. Dalam hal ini prinsipal seharusnya memperoleh informasi yang dibutuhkan dalam mengukur tingkat hasil yang diperoleh dari usaha agen, namun ternyata informasi tentang ukuran keberhasilan yang diperoleh oleh prinsipal tidak seluruhnya disajikan oleh agen. Akibatnya informasi yang diperoleh prinsipal kurang lengkap sehingga tetap tidak dapat menjelaskan kinerja agen yang sesungguhnya dalam mengelola kekayaan prinsipal yang telah dipercayakan kepada agen. Akibat adanya informasi yang tidak seimbang (asimetri) ini, dapat menimbulkan 2 (dua) permasalahan yang disebabkan adanya kesulitan prinsipal untuk memonitor dan melakukan kontrol terhadap tindakan-tindakan agen. Jensen dan Meckling (1976) menyatakan permasalahan tersebut adalah:

(a). Moral Hazard, yaitu permasalahan yang muncul jika agen tidak melaksanakan hal-hal yang telah disepakati bersama dalam kontrak kerja.

(b) Adverse selection, yaitu suatu keadaan dimana prinsipal tidak dapat mengetahui apakah suatu keputusan yang diambil oleh agen benar-benar didasarkan atas informasi yang telah diperolehnya, atau terjadi sebagai sebuah kelalaian dalam tuga

Adanya prilaku moral hazard di atas, menimbulkan biaya keagenan (agency cost), yang menurut Jensen dan Meckling (1976) terdiri dari:

(a) The monitoring expenditures by the principle. Biaya monitoring dikeluarkan oleh prinsipal untuk memonitor perilaku agen, termasuk juga usaha untuk mengendalikan (control) perilaku agen melalui budget restriction, dan compensation policies

(b) The bonding expenditures by the agent. The bonding cost dikeluarkan oleh agen untuk menjamin bahwa agen tidak akan menggunakan tindakan tertentu yang akan merugikan prinsipal atau untuk menjamin bahwa prinsipal akan diberi kompensasi jika ia tidak mangambil banyak tindakan.

(c) The residual loss yang merupakan penurunan tingkat kesejahteraan prinsipal maupun agen setelah adanya agency relationship.

Agency costs yang terjadi menurut teori agency harus dikeluarkan sedemikian rupa, sehingga biaya untuk mengurangi kerugian yang timbul karena ketidakpatuhan setara dengan peningkatan biaya enforcement-nya. Agency costs ini mencakup biaya untuk pengawasan oleh pemegang saham; biaya 
yang dikeluarkan oleh manajemen untuk menghasilkan laporan yang transparan, termasuk biaya audit yang independen dan pengendalian internal; serta biaya yang disebabkan karena menurunnya nilai kepemilikan pemegang saham sebagai bentuk 'bonding expenditures' yang diberikan kepada manajemen dalam bentuk opsi dan berbagai manfaat untuk tujuan menyelaraskan kepentingan manajemen dengan pemegang saham. Asimetri Informasi dalam pengungkapan sosial dapat menciptakan gap antara pihak-pihak yang berkepentingan yang akan menimbulkan ekses moral hazard.

\section{Keterkaitan Corporate Social Responsebility dan Corporate Governance}

Stakeholder khususnya investor mengapresiasai praktik CSR dengan menggunakan program CSR sebagai bahan analisis untuk menilai potensi keberlangsungan usaha dan profitabilitas usaha suatu perusahaan. Pambudi (2006) menjelaskan apabila perusahaan tidak melaksanakan program CSR, stakeholder akan mempersepsikan bahwa perusahaan tersebut tidak melakukan pertanggungjawaban sosialnya dan meragukan keberlangsungan usahanya. Hasil penelitian di beberapa Negara maju membuktikan bahwa investor memasukkan variable CSR untuk pengambilan keputusannya (Nurlela, 2008). Hasil penelitian tersebut mengindikasikan bahwa terdapat peningkatan kepercayaan masyarakat terhadap perusahaan-perusahaan yang melaksanakan program CSR. Murwwaningsari (2008) meneliti 126 perusahaan manufaktur yang terdaftar di BEI dan membuktikan bahwa CSR berpengaruh positip terhadap kinerja keuangan perusahaan.

Dalam perkembangan riset tentang CSR, pengungkapan social (social disclousure) perlu dilakukan dalam praktik yang penuh keterbukaan (transparansi) dan akuntabiltas yang terjamin dari pihak pengelola perusahaan agar pengungkapan social perusahaan semata-mata bukan merupakan strategi pertahanan diri pihak manajemen ketika manajemen melakukan moral hazard. Pengungkapan CSR di definisikan sebagai suatu proses penyediaan informasi yang dirancang untuk mengemukakan masalah seputar social accountability yang mana secara khas tindakan ini dapat dipertanggungjawabkan dalam media-media seperti laporan tahunan maupun dalam bentuk iklaniklan yang berorientasi social. (Gray et al, 2001)

Prior et all beragumen bahwa program CSR digunakan sebagai strategi pertahanan diri manajemen manakala manajemen melakukan moral hazard berupa praktik manajemen laba yang dapat memperburuk kinerja perusahaan dimasa depan. Dengan taktik ini manajemen berharap dapat 
mengurangi kemungkinan memperoleh tekanan akibat ketidakpuasan shareholder dan lainnya yang kepentingannya dirugikan dengan adanya praktik manajemen laba. ( Prior et al, 2008; Orlitzky et al,2003)

Prilaku manipulatif oleh manajer yang berawal dari konflik kepentingan tersebut dapat diminimumkan melalui suatu mekanisme monitoring yang bertujuan untuk menyelaraskan (alignment) berbagai kepentingan. Untuk meminimalkan agency cost yang ada, maka shareholder melakukan pengawasan terhadap pihak manager dengan meminta pengungkapan yang lebih luas, pengungkapan akan lebih meningkat lagi sebanding dengan banyaknya jumlah shareholder external (Woodcock dan Whiting, 2009). Perubahan kebijakan mengenai pengungkapan yang dilakukan perusahaan bertepatan dengan perubahan ekonomi perusahaan dan corporate governance dan struktur corporate governance yang dirancang dengan baik akan memaksimalkan kebijakan dalam hal pengungkapan (Lu et al., 2007).

\section{Keterkaitan CSR Dengan Teori Agensi}

Praktek CSR dan pengungkapannya juga dikaitkan dengan agensi teori. (Cowen dkk,1987;Adams,2002; dan Campbell, 2000 dalam Farok dan Lanis, 2005). Pengungkapan tanggung jawab social merupakan salah satu komitmen manajemen untuk meningkatkan kinerjanya terutama dalam kinerja social. Dengan demikian, manajemen akan mendapatkan penilaian positif dari pemilik. Sehingga menurut Gray et all (1987) dapat dikatakan bahwa pengungkapan tanggung jawab social merupakan perluasan tanggung jawab organisasi di luar peran tradisionalnya untuk menyediakan laporan keuangan kepada pemilik modal khususnya shareholder.

Anggraini (2006) menyatakan bahwa tuntutan terhadap perusahaan untuk memberikan informasi yang transparan, organisasi yang akuntabel serta tata kelola perusahaan semakin bagus (good corporate governance) semakin memaksa perusahaan untuk memberikan informasi mengenai aktivitas sosialnya. Sehingga dapat dikatakan bahwa konsep tata kelola perusahaan yang bagus (good corporate governance) merupakan jawaban atas problem yang dihadapi oleh teori agensi dan juga ilegitimasi dalam pespektif stakeholder. Solusi yang ditawarkan dalam konsep CG tersebut dapat memberikan keyakinan pada para shareholder dan stakeholder terhadap manajemen pengelola perusahaan. Dalam perspektif teori agensi gap atau senjangan antara pihak agen dan principal yang berupa asimetri informasi dapat disejajarkan kembali. Sehingga secara konseptual landasan 
pemikiran teoritisnya keterkaitan antara CSR dan Corporate Governance (CG) dapat digagambarkan dalam dua bagan sebagai berikut :

Pada tahap pertama secara internal perusahaan menghadapi konflik dengan shareholder sebagai akibat dari asimetri informasi yang memunculkan agensi problem. Dan secara eksternal menghadapi gap excpectations dari stkeholdernya. Teoritikal dasar perspektif shareholder dan perspektif stakeholder digambarkan sebagai berikut:

Perspektif Shareholder

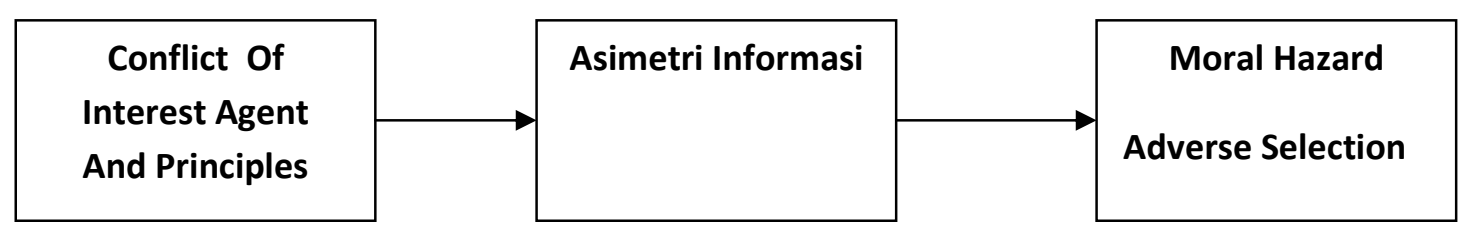

Perspektif Stakeholder

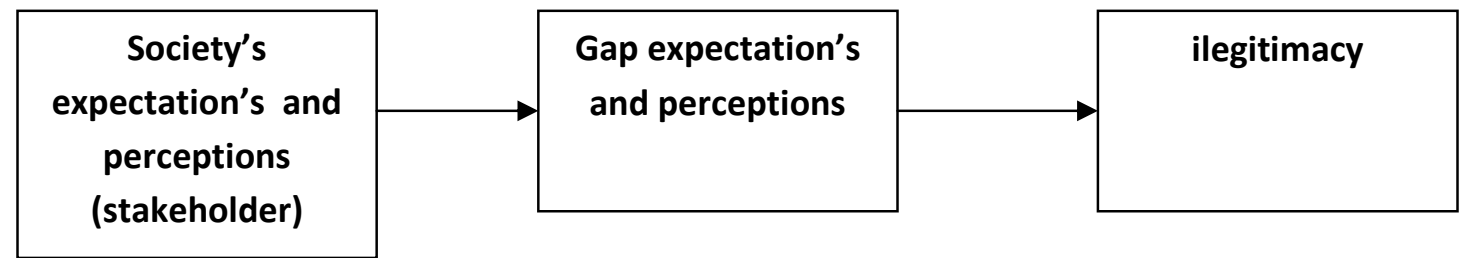

Kemudian dalam tahap kedua seiring dengan perkembangan dan kompleksitas yang dihadapi perusahaan, terjadi perluasan dari perspektif shareholder ke perspektif stakeholder. Aktifitas perusahaan tidak hanya menghadapi tantangan konflik kepentingan secara internal terhadap shareholdernya tetapi juga menghadapi tantangan berupa ilegitimasi dari stakeholdernya. Menghadapi dua tantangan yang berasal dari internal maupun sisi ekstenal tersebut perusahaan menjawab dengan penerapan sisitim CG. Sehingga keterkaitan CSR dengan CG dapat digambarkan dalam bagan sebagai berikut :

\section{Bagan Keterkaitan CG dengan CSR}

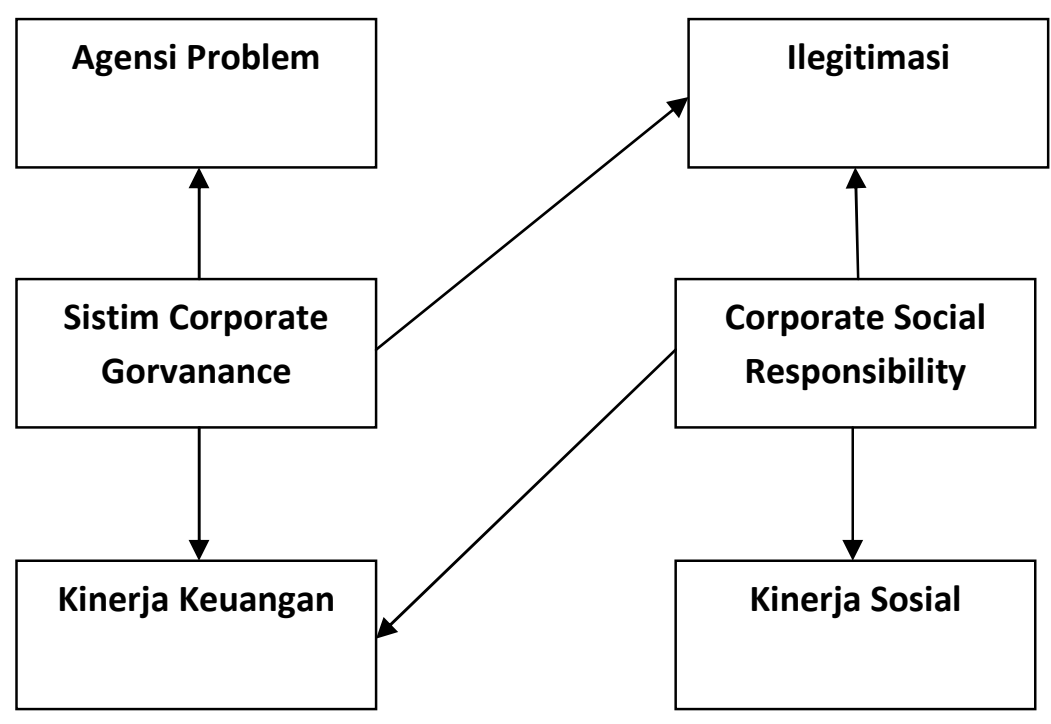


Konflik antara manajer (agen) dan shareholder (principal) atau yang sering disebut dengan masalah keagenan dapat diminimumkan dengan sebuah mekanisme atau sistim corporate governance yang dapat mensejajarkan kepentingan principal dan agen. Dengan demikian otomatis simetri infomasi akan terjadi yang berdampak pada kinerja keuangan. Tentu saja bila sistim CG tidak bekerja dengan baik maka akan direspon oleh pihak shareholder berupa tekanan dari pihak principal (shareholder) kepada manajer (agen). Dalam pendekatan entity sistim CG dapat berperan didalam mengatasi ilegitimasi dalam perspektif stakeholder theory, dimana tekanan kepada aktifitas perusahaan tidak hanya dilakukan oleh shareholder tetapi juga stakeholder. Perusahaan berharap dengan penerapan CSR akan memperoleh legitimasi social kembali sekaligus memaksimalkan kekuatan keuangan dalam jangka panjang (Kiroyan,2006). Dan juga maemaksimalkan kinerja sosialnya. Ulmann (1985) menyatakan bahwa dampak dari peningkatan kinerja social yang diungkapkan perusahaan dapat mempengaruhi kinerja ekonomi yang diukur dengan rasio-rasio dalam laporan keuangan maupun kinerja saham dipasar modal.

\section{Kesimpulan}

Perusahaan menghadapi tantangan dari dua lini sekaligus. Pertama adanya persepsi dari stakeholdernya bahwa aktifitas perusahaan untuk memaksimumkan keuntungan mungkin akan berdampak buruk bagi lingkungannya. Baik dampak buruk terhadap produk yang merusak lingkungan, pelanggaran hak asasi pekerjanya, maupun dampak buruk lainnya. Dan kedua bahwa pada kenyataannya sebagian dari perusahaan-perusahaan tidak mengikuti peraturan. (Beltarti, 2005). Sebuah sistim corporate gorvernance yang efektif akan mendukung corporate social responsibility. Corporate governance dan Social Responsibility keduanya memiliki hubungan yang sangat kuat. Keduanya membentuk fungsi yang objektif dalam menghadapi kendala perusahaan. Disatu sisi CG dapat meminimalkan biaya agensi disisi lain CSR dapat mengatasi beban ilegitimasi dari stakeholdernya. Baik CG maupun CSR memiliki hubungan imbal balik yang membentuk fungsi yang mampu meningkatkan nilai perusahaan dan meningkatkan kinerja social dan kinerja keuangan dalam jangka panjang. 


\section{DAFTAR PUSTAKA}

Anggraini RR, 2006. Pengungkapan Informasi Sosial dan Faktor-faktor yang Mempengaruhi Pengungkapan Informasi Sosial dalam Laporan Keuangan Tahunan Studi Empiris pada Perusahaan-perusahaan yang terdaftar di Bursa Efek Jakarta. Simposium Nasional Akuntansi 9, 23-26 Agustus. Padang .

Basalamah, AS \& Jermias. 2005. Social and Enviromental Reporting and Auditing in Indonesia. Gajah Mada International Journal of Business, Vol. 7, pp 109-127

Belkaoui, A and Karpik P.G, 1989. Determinan of the Corporate Decision to Disclose Social information. Auditing and Accountability journal. Vol 1 No 1

Beltratti, Andrea, 2005. The Complementarity between Corporate Governance and Corporate Social Responsibility . The Geneva paper, pp 373-386

Clarkson,M, 1994. A Risk Based Model of Stakeholder Theory. Proceedings of the Second Toronto Conference on Stakeholder Theory. Centre for Corporate Social Performance and Ethics. University of Toronto. Toronto

Deegan,C,2000. Financial Accounting Theory. Rosevill,NSW: McGraw-Hill

Jensen, Michael Cand Williem H. Meckling. 1976. Theory of The Firm, Manager Behavior, Agency Cost and Ownership Structure, Journal of Financial Economic 3 No 4 : 305-360

Lu, Chilin, et al. 2007. Ownership and Firm Value in Emeging Market. Social Science Research Network, pp 1-38.

Murwaningsari, E, 2009. Hubungan Corporate Governance, Corporate Social Responsibility dan Corporate Financial Perfprmance dalam Satu Continum, Jurnal Akuntansi dan Keuangan, Vol 11 No 1 pp 30-41

Restuningdiah, 2010. Mekanisme GCG Dan Pengungkapan Tanggung Jawab Sosial Terhadap Koefisien Respon Laba. Jurnal Keuangan dan Perbankan, Vol 14, No 3 September 2010, hlm 377-390

Gray, Javad M, David MP, \& Donald, 2011. Social and Environmental Disclosure and Corporate Characteristic, Journal of Business Finance and Accounting, pp 327-356 
Gray, Owen, D \& Adam, 1996. Accounting and Accountability, Journal Hemel Hempstead : Prentics Hall.

Shane P.B \& Spicer, B.H, 1983.. Social Mareket Response to environmental information Product Outside the firm. Accounting Review, Vol 58 pp 521-536.

Ujiyantho, MA \& Pramuka,BA,2007. Mekanisme Corporate Governance,Manajemen Laba dan Kinerja Keuangan,Simposium Nasional Akuntansi X, 26-28 Juli, Makasar.

Ullmann. A.R, 1985, Data in Search of a Theory : A Critical Examination of The Relationships Among Social Performance, Social Disclosure,and Economic Performance of U.S Firm. Academy of Management. Vol. 10 No.3 540-557 